\title{
Strategi Pengembangan Pariwisata Bahari Desa Pulau Benan Kecamatan Senayang Kabupaten Lingga Provinsi Kepulauan Riau
}

\author{
Akhirmana, Nurhasanah \\ Fakultas Ekonomi Universitas Maritim Raja Ali Haji, Tanjungpinang, Kepulauan Riau, Indonesia
}

\begin{abstract}
ABSTRAK :Desa Pulau Benan merupakan salah satu desa yang berada dalam Kecamatan Senayang Kabupaten Lingga ternyata memiliki potensi Wisata Bahari yang layak untuk dikembangkan menjadi wisata unggul di Provinsi Kepeulauan Riau setelah Lagoi. Kepri berhasil membukukan Rp 4,8 triliun dari industri pariwisata sepanjang tahun 2017 lalu. Nominal itu merupakan asumsi dari uang yang dibelanjakan wisatawan domestik dan mancanegara. Sepanjang Januari hingga November 2017 lalu, jumlah wisatawan mancanegara (wisman) yang berkunjung ke Kepri mencapai 1.815.978. Jumlah itu naik 6,29 persen dibanding periode yang sama 2016 lalu. Saat itu, wisman yang berlibur ke Kepri berjumlah 1.708.500. Namun data kunjungan wisatawan ke Objek Wisata Pulau Benan masih tergolong rendah, dalam catatan Dinas Pariwisata Pemuda dan Olahraga (Disparpora, Kab.Lingg; 2016) Kabupaten Lingga kunjungan wisatawan ke Pulau Benan tersebut tahun 2018 hanya dalam hitungan puluhan wisatawan dari mancanegara. (Disparpora, Kab.Lingga; 2016).

Kendala transportasi dari Tanjungpinang, Batam atau dari Lingga untuk datang ke Pulau Benan masih terbatas bahkan spekulatif sekali. Jika terjadi cuaca buruk seperti angin kencang maka Ferry atau Speed Baod yang ditompangi tidak dapat merapat untuk singgah di Pelabuhan satu-satunya pelabuhan penumpang, kemudian Ongkos transportasi yang tidak proporsional. Penelitian ini bertujuan untuk mengetahui strategi pengembangan objek wisata Desa Pantai Pulau Benan agar menarik minat wisatawan untuk datang ke objek wisata tersebut.Penelitian ini menggunakan metode deskriptif kualitatif. Berdasarkan hasil penelitian, pengembangan strategi pariwisata Desa Pantai Pulau Benan dapat dirumuskan dengan menggunakan SWOT dan strategi analisis SO, ST, WO, WT. dengan menerapkan Pariwisata Berbasis Masyarakat sebagai pendekatan untuk pengembangan pariwisata.
\end{abstract}

Kata kunci:Pengembangan Strategi, Potensi, Desa Wisata.

Email Address : 4khirman@gmail.com 


\section{PENDAHULUAN}

Indonesia memiliki keanekaragaman pariwisata. Keanekaragaman yang begitu banyak dan unik dari masing-masing Negara, masing-masing daerah, merupakan kekayaan suatu Negara atau daerah. Paradigma pariwisata kerakyatan dalam berbagai bentuk telah menjadi paradigma alternative untuk dapat memberi pemerataan pembangunan dan pemerataan kesejahteraan menuju pariwisata berkelanjutan.

Pembangunan pariwisata pedesaan diharapkan menjadi suatu model pembangunan pariwisata berkelanjutan sesuai kebijakan pemeritah dibidang pariwisata. Pembangunan Desa Pariwisata yang berkelanjutan diformulasikan sebagai pembangunan yang berusaha memenuhi kebutuhan hari ini, dan mewariskannya kepada genenrasi yang akan datang.

Pembangunan Desa Pariwisata yang dilaksanakan hendaknya berkelanjutan, pembangunan berkelanjutan bukan hanya dalam bentuk konsep belaka, akan tetapi diikuti oleh komitmen dari berbagai pihak dan juga komitmen dari pemerintah untuk tetap menjaga kelestarian lingkungan alam yang harmonis, social ekonomi kerakyatan yang semakin baik, serta kelestarian dan pengembangan kebudayaan kerakyatan adalah sebagai modal dasar pengembangan Desa Pariwisata. Pitana (2002) menyatakan dalam pariwisata berkelanjutan, penekanan berkelanjutan tidak cukup hanya cukup berkelanjutan ekologis dan berkelanjutan ekonomi, tatapi yang tidak kalah pentingnya adalah keberlanjutan kebudayaan, karena kebudayaan merupakan salahs satu sumberdaya yang dimiliki masing-masing negara, masing-masing daerah, masing-masing suku yang unik dan sangat penting dalam pembangunan Kepariwisataan.

lementasi dari konsep-konsep ini di aplikasikan dalam program pengembangan pariwisata pedesaan. Sehingga pengembangan pariwisata tesebut tetap menjaga kelestarian lingkungan, nilai sosial ekonomi, dan nilai-nilai kebudayaan sebagai unsur pemersatu NKRI.

Banyaknya bentuk karya seni dan kebudayaan masyarakat di Indonesia khususnya masyarakat di Provinsi Kepulauan Riau, dapat menjadi daya tarik bahkan menjadi peluang usaha baru dalam menarik minat wisatawan untuk datang beramai-ramai kepada objek wisata yang ada khususnya Objek Wisata Desa Pantai Pulau Benan. Selama ini masyarkat hanya mengenal objek wisata Desa Pantai Pulau Benan sebagai tempat mandi, berenang, dudukduduk santai, istirahat sekedar menghilangkan penat. Atau hanya sekedar jalan-jalan bagi wisatawan mancanegara. Karena memang kurannya pengembangan SDM untuk menciptakan sesuatu produk atau karya seni dalam bidang kebudayaan. Kini sudah banyak objek wisata yang menyajikan berbagai produk kerajinan masyarakat setempat, dan acara adat penyambutan tamu (wisatawan) salah satu tujuannya adalah untuk memanjakan wisatawan dengan berbagai produk yang menarik dan tontonan budaya yang ramah dan unik.

Pariwisata telah menjadi salah satu industri terbesar di berbagai Negara di dunia, setelah minyak bumi dan gas. Pariwisata juga merupakan andalan utama dalam menghasilkan devisa di berbagai negara tanpa terkecuali Indonesia. Pengembangan pariwisata di Indonesia pada akhir-akhir ini berjalan sangat pesat. Hal ini sejalan dengan usaha pemerintah Indonesia Journal of Development and Social Change, Vol. 1, No. 1, April 2018: P. 9-17 pISSN 2614-5766, https: //jurnal.uns.ac.id/jodasc Karina Wulan Sayogi, Argyo Demartoto. Untuk mengembangkan pariwisata di Indonesia dengan sebanyak mungkin menarik wisatawan mancanegara yang dapat dijadikan sebagai sumber devisa di Indonesia (Hardjowigeno dan Widiatmaka, 2013).

Pariwisata merupakan bagian dari pembangunan yang bersifat multi-dimensional yang berdampak di berbagai aspek kehidupan. 
Pariwisata yang sekarang menjadi sumber devisa negara ini menunjukan suatu realitas sosial dimana pariwisata merupakan fenomena yang kompleks, bukan sekedar kegiatan dengan objek utama industri pelayanan yang melibatkan manajemen produk dan pasar, tetapi lebih dari itu merupakan suatu proses dialog antara wisatawan sebagai guest dan masyarakat lokal sebagai host. (Demartoto, 2009).

Pengembangan pariwisata yang seperti ini dianggap lebih tepat dan proporsional bagi kesejahteraan khususnya ma-syarakat lokal. Dari studi-studi atas berbagai proyek pengembangan pari-wisata tersebut terlihat suatu pola yang relatif sama tentang bagaimana seharusnya pengembangan pariwisata dilakukan dan dikelola agar dapat meningkatkan kesejahteraan masyarakat khususnya di sekitar kawasan wisata.

Pembangunan pariwisata yang ini sedang gencar-gencarnya diterapkan oleh berbagai wilayah di Indonesia. Lagoi sebagai ikon pariwisata Indonesia pun telah banyak melibatkan peran serta masyarakat dalam pembangunan pariwisata begitu juga dengan wilayah lain. Studi-studi tentang kepariwisataan yang telah banyak dilakukan. Salah satunya adalah tentang studi pengembangan pariwisata di Kepulauan Karimun Jawa yang menganalisis tentang potensi dan atraksi wisata, mengidentifikasi karakteristik masyarakat lokal serta peran serta masyarakat dalam pengembangan pariwisata di Kepulauan Karimun Jawa (Elida, 2005).

Desa Benan, Kecamatan Senayang Kabupaten Lingga, masih banyak menyimpan objek-objek wisata lainya selain Wisata Pantai Desa Pulau Benan, serta aktivitas wisata lainnya selain menikmati keindahan pantainya yang ramah lingkungan, jernih dan penuh pesona. Meskipun sudah cukup dikenal, namun kawasan wisata ini posisinya masih banyak kelemahannya, untuk dijadikan distinasi utama setelah Lagoi. Maka perlu identifikasi permasalahan apa yang menghambat perkembangan tersebut. Selanjutnya dapat dikembangkan menggunakan strategi yang sesuai dengan kebutuhan masyarakat lokal karena masyarakat lokal sebagai salah satu faktor utama dalam pengembangan pariwisata. Pantai Desa Pulau Benan sebagai salah satu destinasi tujuan wisata (tourist destination area) perlu dilakukan pengembangan secara berkelanjutan dan partisipatif sebagai upaya untuk meningkatkan daya tarik bagi wisatawan yang pada akhirnya akan meningkatkan pendapatan masyarakat maupun Pendapatan Asli Daerah (PAD).

\section{Rumusan masalah}

Berdasarkan latar belakang di atas, dapat dirumuskan permasalahan sebagai berikut: Bagaimana Strategi Pengembangan potensi Wisata Desa Pulau Benan.

\section{Tujuan Penelitian}

Adapun tujuan penelitian untuk mengetahu strategi pengembangan potensi Wisata Bahari Desa Pulau Benan.

\section{LANDASAN TEORI}

\section{Desa Wisata}

Menurut Priasukmana \& Mulyadin (2001), Desa Wisata merupakan suatu kawasan pedesaan yang menawarkan keseluruhan suasana yang mencerminkan keaslian pedesaaan baik dari kehidupan sosial ekonomi, sosial budaya, adat istiadat, keseharian, memiliki arsitektur bangunan dan struktur tata ruang desa yang khas, atau kegiatan perekonomian yang unik dan menarik serta mempunyai potensi untuk dikembangkanya berbagai komponen kepariwisataan, misalnya atraksi, akomodasi, makanan-minuman, cindera-mata, dan kebutuhan wisata lainnya.

Sementara itu David (2004) dalam Dharasta (2017) mengatakan bahwa lingkungan eksternal terdiri dari : Kekuatan ekonomi, 
Sinergitas Quadruple Helix: e-Business dan Fintech sebagai Daya Dorong Pertumbuhan Ekonomi Lokal 178 kekuatan sosial, budaya demografi dan lingkungan, kekuatan politik pemerintahan dan hukum, kekuatan teknologi, dan kekuatan kompetitif.

\section{David (2004) dalam Dharasta} (2017) mengatakan bahwa analisis lingkungan internal membutuhkan pengumpulan asimilasi, dan evaluasi tentang operasi perusahaan. Analisis internal berguna untuk mengetahui aspek kekuatan dan kelemahan yang merupakan faktor - faktor penentu keberhasilan.

Desa wisata biasanya berupa kawasan pedesaan yang memiliki beberapa karakteristik khusus yang layak untuk menjadi daerah tujuan wisata. Dikawasan ini, penduduknya masih memiliki tradisi dan budaya yang relative masih asli. Selain itu, beberapa faktor pendukung seperti makanan khas, sistem pertanian dan sistem sosial turut mewarnai sebuah kawasan desa wisata. Di luar faktor-faktor tersebut, sumberdaya alam dan lingkungan alam yang masih terjaga merupakan salah satu faktor penting dari sebuah kawasan desa wisata.

Selain berbagai keunikan tersebut, kawasan desa wisata juga dipersyaratkan memiliki berbagai fasilitas untuk menunjangnya sebagai kawasan tujuan wisata. Berbagai fasilitas ini akan memudahkan para pengunjung desa wisata dalam melakukan kegiatan wisata. Fasilitas-fasilitas yang seyogyanya ada disuatu kawasan desa wisata antara lain : sarana transportasi, telekomunikasi, kesehatan, dan akomodasi. Khusus untuk sarana akomodasi, desa wisata dapat menyediakan sarana penginapan berupa pondok-pondok wisata (Home Stay) sehingga para pengunjung dapat merasakan suasana pedesaan yang masih asli.Menurut Priasukmana dan Mulyadin (2001), penetapan suatu desa dijadikan sebagai desa wisata harus memenuhi persyaratanpersyaratan, antara lain sebagai berikut :
1. Aksesibilitasnya baik, sehingga mudah dikunjungi wisatawan dengan menggunakan berbagai jenis alat transportasi.

2. Memiliki obyek-obyek menarik berupa alam, seni budaya, legenda, makanan lokal, dan sebagainya untuk dikembangkan sebagai obyek wisata.

3. Masyarakat dan aparat desanya menerima dan memberikan dukungan yang tinggi terhadap desa wisata serta para wisatawan yang datang kedesanya.

4. Keamanan di desa tersebut terjamin.

5. Tersedia akomodasi, telekomunikasi, dan tenaga kerja yang memadai.

6. Beriklim sejuk atau dingin.

7. Berhubungan dengan obyek wisata lain yang sudah dikenal oleh masyarakat luas.

\section{Komponen Desa Wisata}

Menurut Gumelar (2010) terdapat empat komponen Desa Wisata, yaitu.

1. Keunikan, keaslian, sifat khas

2. Letaknya berdekatan dengan daerah alam yang luar biasa

3. Berkaitan dengan kelompok atau masyarakat berbudaya yang secara hakiki menarik minat pengunjung

4. Memiliki peluang untuk berkembang baik dari sisi prasarana dasar, maupun sarana lainnya.

\section{Komponen Pengembangan Desa Wisata}

Komponen-komponen pengembangan desa wisata menurut Karyono (1997) adalah :

1. Atraksi dan kegiatan wisata, atraksi wisata dapat berupa seni, budaya. 
Warisan, sejarah, tradisi, kekayaan alam, hiburan, jasa dan lain yang merupakan daya tarik wisata.

2. Akomodasi, akomodasi pada desa wisata yaitu sebagian dari tempat tinggal penduduk setempat dan atau unit-unit yang berkembang atas konsep tempat tinggal penduduk.

3. Unsur institusi atau kelembagaan dan SDM, dalam pengembangan desa wisata lembaga yang mengelola harus memiliki kemampuan yang handal.

4. Fasilitas pendukung wisata lainnya, pengembangan desa wisata harus memiliki fasilitas-fasilitas pendukung seperti sarana komunikasi.

5. Infrastruktur lainnya, insfrastruktur lainnya juga sangat penting disiapkan dalam pengembangan desa wisata seperti sitem drainase.

6. Transportasi menjadi hal sangat penting bagi akses tamu

7. Sumber daya baik lingkungan maupun sosial budaya

8. Masyarakat, dukungan masyarakat sangat besar peranannya seperti menjaga kebersihan lingkungan, keamanan, keramah tamahan.

9. Pasar domestik dan Mancanegara, pasar desa wisata dapat berasal dari domestik

maupun mancanegara.

\section{Analisis SWOT}

Menurut Freddy (2004) Proses pengambilan keputusan strategi selalu berkaitan dengan pengembangan misi, tujuan, strategi dan kebijakan perusahaan. Dengan demikian, perencanaan strategi harus menganalisa faktor kekuatan, kelemahan, peluang dan ancaman) dalam kondisi yang saat ini. Analisa SWOT menggambarkan situasi dan kondisi yang sedang dihadapi dan mampu memberikan solusi untuk permasalahan yang sedang dihadapi. Komponen amalisis SWOT ada 4 yaitu:

1. Strenght-S (Kekuatan); Analisa kekuatan merupakan kondisi kekuatan yang dimiliki suatu daerah atau organisasi dari apa yang dimilikinya. Kekuatan ini dimanfaatkan untuk dikembangkan atau digunakan menghadapi tantangan.

2. Weakness- W (Kelemahan); Analisa kelemahan merupakan kelemahan yang ada di pada daerah tersebut atau organisasi. Kelemahan ini bisa menjadi kendala dalam kelangsungan pembangunan atau organisasi mencapai tujuannya.

3. Opprtunity-O (Peluang); Analisa peluang ini menggambarkan kondisi dan situasi baik yang dimiliki di daerah tersebut, atau karena factor kebutuhan dari Luar dari daerah. Yang dapat dikembangkan lebih baik dari sebelumnya.

4. Threats-T (Ancaman); Analisa ancaman menggambarkan tantangan atau ancaman yang harus dihadapi daerah dalam segala aspek atau pada organisasi. Ancaman ini berasal dari berbagai macam faktor lingkungan yang tidak mendukung, dan dapat menyebabkan kemunduran, bahkan Keempat komponen di atas dituangkan dalam matrik SWOT.

Matrik ini dapat mengambarkan secara jelas peluang dan ancaman (faktor eksternal) yang dihadapi organisasi dapat disesuaikan dengan kekuatan dan kelemahan yang dimilikinya 
Kotler (2000) mengelompokkan faktor faktor lingkungan eksternal sebagai bagian dari lingkungan makro, dan menambahkan aspek demografi dan alam kedalamnya. Kekuatan kekuatan yang ada didalam lingkungan makro ini tidak dapat dikendalikan dan harus dipantau serta ditanggapi oleh perusahaan karena lingkungan ini memberikan peluang sekaligus ancaman. Sementara itu David (2004) dalam Dharasta (2017) mengatakan bahwa lingkungan eksternal terdiri dari : Kekuatan ekonomi, kekuatan sosial, budaya demografi dan lingkungan, kekuatan politik pemerintahan dan hukum, kekuatan teknologi, dan kekuatan kompetitif. David (2004) dalam Dharasta (2017) mengatakan bahwa analisis lingkungan internal membutuhkan pengumpulan asimilasi, dan evaluasi tentang operasi perusahaan. Analisis internal berguna untuk mengetahui aspek kekuatan dan kelemahan yang merupakan faktor - faktor penentu keberhasilan.

\section{METODOLOGI}

Jenis penelitian yang digunakan dalam penelitian ini adalah deskriptif kualitatif. Iskandar (2008) dalam Fitra (2012) menjelaskan bahwa penelitian deskriptif kualitatif adalah pendekatan sistematis dan subjektif dalam menjelaskan segala sesuatu yang ada di lapangan (bersifat empiris) serta berorientasi kepada upaya untuk memahami fenomena secara menyeluruh. Dalam mendapatkan informasi mengenai data terkait penulis menggunakan metode studi literatur melalui data sekunder dari buku, jurnal terkait, data dari Bank Indonesia, Kementrian Pariwisata dan Kebudayaan, Dinas Pariwisata, situs resmi Desa Pulau Benan, dan menggunakan analisis SWOT untuk mengetahui kekuatan, kelemahan, peluang dan ancaman sehingga dapat disimpulkan strategi yang relevan untuk mendukung upaya Desa Pulau Benan menjadi desa wisata. Freddy (2014) menyatakan bahwa Analisis SWOT adalah instrumen perencanaan strategi yang klasik dengan mengunkakan kerangka kerja kekutan dan kelemahan, pelung dan ancaman, instrumen ini memberikan cara sederhana untuk memperkirakan cara terbaik untuk melaksanakan suatu strategi.

\section{HASIL DAN PEMBAHASAN}

Tujuan dari tahapan ini adalah mengetahui lingkungan internal dan eksternal dengan tujuan mengetahui kekuatan atau fasilitas yang dimiliki sehingga nantinya dapat ditemukan strategi berdasarkan identifikasi sumber daya yang dimiliki (Saryasat, 2013) Berikut merupakan tabel dari kekuatan dan kelemahan Desa Sidomekar terhadap beberapa aspek meliputi Ekonomi, Sosial budaya, Lingkungan dan pemerintah terkait dalam upaya mengidentifikasi kekuatan dan kelemahan di masing-masing aspek ang dapat mendorong dan menghambat upaya desa Sidomekar menjadi desa wisata.

Tabel. 1. Matrik sector internal

\begin{tabular}{|c|c|c|}
\hline Dimensi & Strengh & Weaknes \\
\hline Ekonomi & 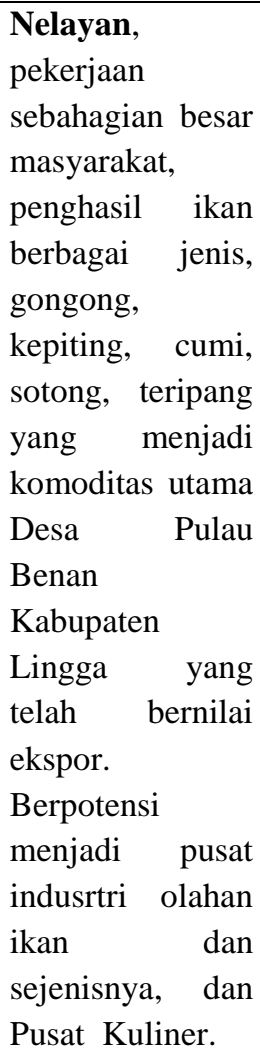 & 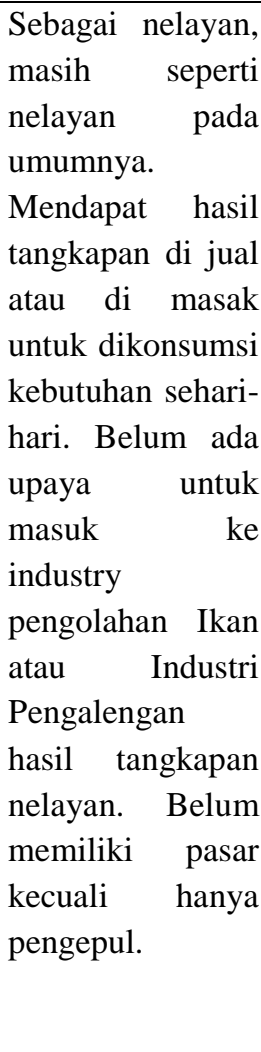 \\
\hline
\end{tabular}




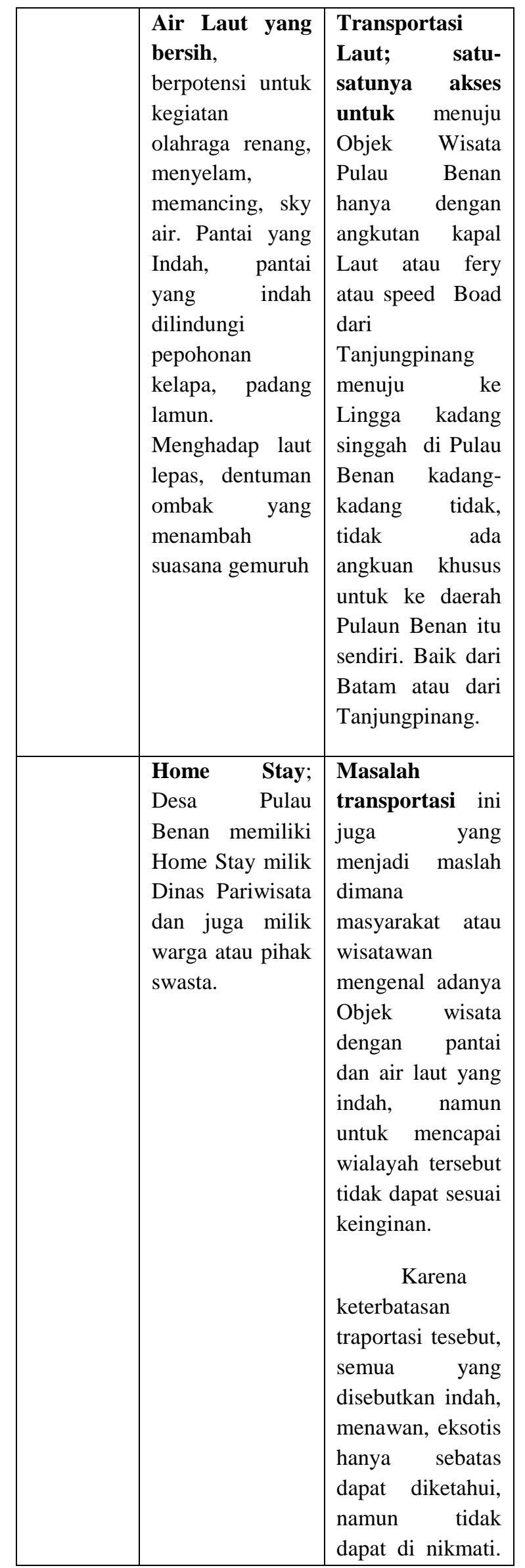

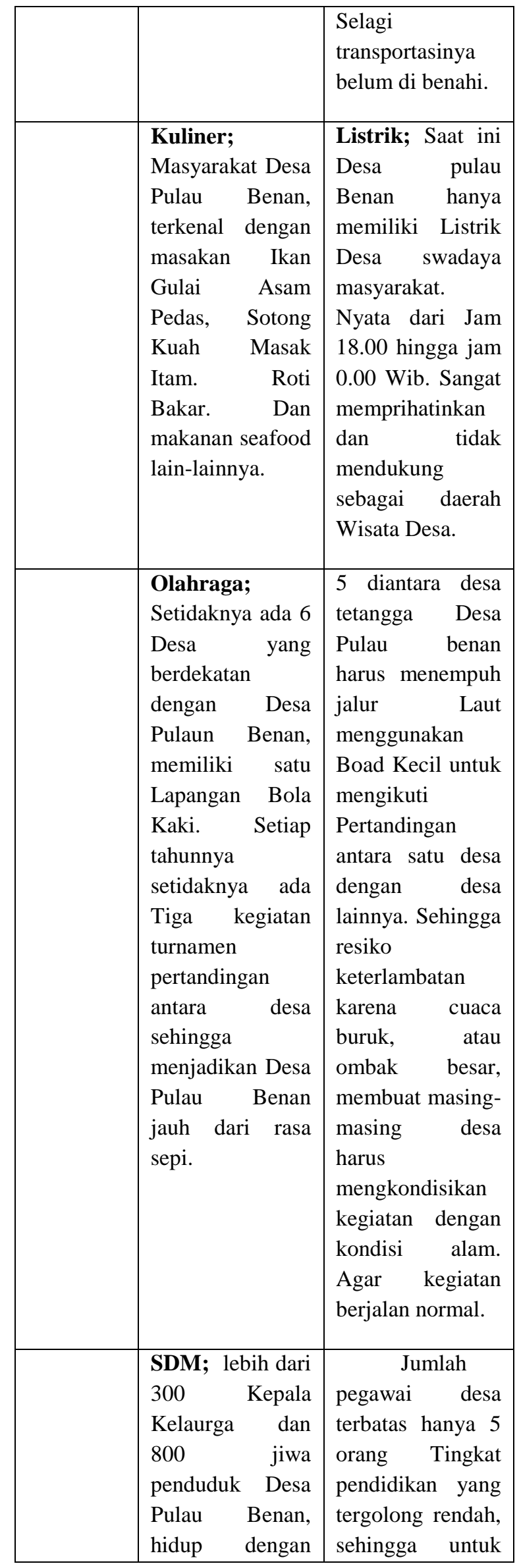




\begin{tabular}{|c|c|c|}
\hline & $\begin{array}{l}\text { rukun, hanya } \\
\text { sekitar } 20 \text { persen } \\
\text { saja } \\
\text { berpendidikan } \\
\text { sarjana. } \\
\text { Selebihnya } \\
\text { SLTA ke bawah. } \\
\text { SDA; Sumber } \\
\text { Daya Alam, baik } \\
\text { Laut yang jernih, } \\
\text { Pantai yang elok, } \\
\text { Padang Lamun } \\
\text { yang Luas, } \\
\text { Bebatuan yang } \\
\text { terjal menambah } \\
\text { semangat untuk } \\
\text { menyepi duduk } \\
\text { di bebatuan pagi } \\
\text { dan sore hari } \\
\text { menjelang } \\
\text { malam. }\end{array}$ & $\begin{array}{l}\text { mengambil } \\
\text { peluang } \\
\text { mengembangan } \\
\text { Objek Wisata } \\
\text { menjadi wisata } \\
\text { modern masih } \\
\text { memerlukan } \\
\text { dukungan dari } \\
\text { pihak luar dari } \\
\text { daeraha tersebut. }\end{array}$ \\
\hline & $\begin{array}{l}\text { Tanaman dan } \\
\text { Buah-buahan; } \\
\text { Ada musim buah } \\
\text { mangga, } \\
\text { rambutan, dan } \\
\text { rambai. } \\
\text { Sewaktu-waktu } \\
\text { tiba musim } \\
\text { panen, hampir } \\
\text { tidak ada } \\
\text { harganya }\end{array}$ & $\begin{array}{l}\text { Sifatnya } \\
\text { musiman, } \\
\text { sehingga kadang } \\
\text { wisatawan tidak } \\
\text { menemukan } \\
\text { makanan seperti } \\
\text { buah-buahan jika } \\
\text { memang tidak } \\
\text { musimkan. }\end{array}$ \\
\hline Penduduk & $\begin{array}{lr}\text { Memiliki } & 600 \\
\text { penduduk } & \text { usia } \\
\text { kerja } & \text { dan } \\
\text { sejumlah } & 200 \\
\text { jumlah penduduk } \\
\text { usia } & \text { kerja } \\
\text { produktif dengan } \\
\text { total penduduk } \\
\text { berjumlah } 800 \\
\text { jiwa. }\end{array}$ & 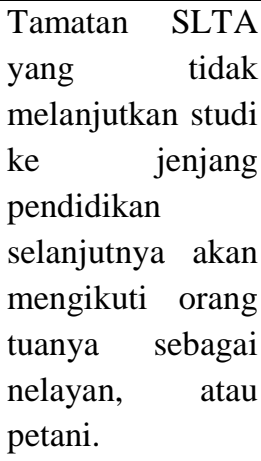 \\
\hline $\begin{array}{l}\text { Lingkung } \\
\text { an }\end{array}$ & $\begin{array}{l}\text { Desa Pulau } \\
\text { Benan dikelilingi } \\
\text { oleh laut, } \\
\text { pencahayaan } \\
\text { yang bagus pagi } \\
\text { dan sore hari. }\end{array}$ & $\begin{array}{lr} & \text { Masyaraka } \\
\text { t } \text { belum menjual } \\
\text { informasi } \\
\text { seperti bersihnya } \\
\text { Laut } \\
\text { Benan, Indahnya }\end{array}$ \\
\hline
\end{tabular}

\begin{tabular}{|c|c|c|}
\hline & $\begin{array}{l}\text { Dilingungi } \\
\text { pohon kelapa, } \\
\text { Padang Lamun, } \\
\text { pasir yang putih, } \\
\text { air jernih. Tidak } \\
\text { ada sampah yang } \\
\text { dibuang ke Laut. } \\
\text { Memiliki visi } \\
\text { misi yang terus } \\
\text { diupayakan } \\
\text { dapat tercipta } \\
\text { melalui program } \\
\text { kerja seperti } \\
\text { menggalakkan } \\
\text { pembangunan } \\
\text { desa, desa } \\
\text { memperbaiki } \\
\text { kebersihan desa, } \\
\text { melaksanakan } \\
\text { berbagai festival } \\
\text { seperti festival } \\
\text { kuliner, seni } \\
\text { dan beberapa } \\
\text { kegiatan lain } \\
\text { yang dilakukan } \\
\text { saat hari besar } \\
\text { menjadi suatu } \\
\text { bentuk kensistensi } \\
\text { semangat } \\
\text { masyarakan } \\
\text { desa. Menyadari } \\
\text { pentingnya } \\
\text { pembangunan } \\
\text { infrasruktur } \\
\text { untuk } \\
\text { menyiapkan } \\
\text { werintisan da. }\end{array}$ & $\begin{array}{l}\text { Pencahayaan } \\
\text { Pagi dan Sore } \\
\text { Pulau Benan, } \\
\text { keindahan } \\
\text { Padang Lamun } \\
\text { Pulau Benan, } \\
\text { Lingkungan } \\
\text { penduduk } \\
\text { dikelilingi Laut } \\
\text { Pulau Benan. } \\
\text { Kemudian } \\
\text { dibagian darat, di } \\
\text { halaman, dan } \\
\text { jalan masih } \\
\text { banyak sampah } \\
\text { kotoran Kambing } \\
\text { ternak warga } \\
\text { masyarakat yang } \\
\text { harus ditertibkan. }\end{array}$ \\
\hline $\begin{array}{l}\text { Sosial } \\
\text { Budaya }\end{array}$ & $\begin{array}{l}\text { Sosial Budaya; } \\
\text { Masyarakat Desa } \\
\text { Pulau Benan, } \\
\text { kaya akan } \\
\text { kegiatan seni dan } \\
\text { budaya. Berbagai } \\
\text { karya seni tari } \\
\text { dan musik } \\
\text { menjadi } \\
\text { kebanggaan } \\
\text { masyarakat yang }\end{array}$ & $\begin{array}{l}\text { Masyarakat } \\
\text { belum } \\
\text { memanfaatkan } \\
\text { potensi laut } \\
\text { sebagai pemicu } \\
\text { untuk hadirnya } \\
\text { wisatawan lebih } \\
\text { banyak dan terus } \\
\text { menerus datang } \\
\text { ke desa tersebut. } \\
\text { Karena minimnya }\end{array}$ \\
\hline
\end{tabular}




\begin{tabular}{|c|c|c|}
\hline & $\begin{array}{l}\text { masih perlu } \\
\text { kembangkan dan } \\
\text { dihidupkan } \\
\text { kembali. Setiap } \\
\text { tahunnya } \\
\text { minimal ada } \\
\text { empat kegiatan } \\
\text { bidang seni dan } \\
\text { budaya. Dari } \\
\text { Tingkat Desa, } \\
\text { Kecamatan, dan } \\
\text { Kabupaen dan } \\
\text { Provinsi. }\end{array}$ & $\begin{array}{l} \\
\text { Kurangnya } \\
\text { pemahaman } \\
\text { mengenai konsep } \\
\text { desa wisata Tidak } \\
\text { adanya } \\
\text { pengawasan } \\
\text { langsung dan } \\
\text { berkala } \\
\text { pemerintah dari } \\
\text { daerah yang lebih } \\
\text { tinggi terhadap } \\
\text { upaya perintisan } \\
\text { desa wisata. }\end{array}$ \\
\hline & $\begin{array}{l}\text { Table2. Matriks } \\
\text { faktor } \\
\text { Eksternal }\end{array}$ & \\
\hline Dimensi & Opportunity & Threat \\
\hline Ekonomi & 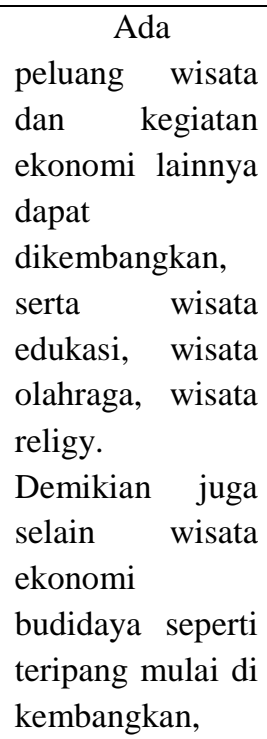 & $\begin{array}{l}\text { Minimnya } \\
\text { modal sehingga } \\
\text { BPD tidak dapat } \\
\text { berbuat banyak } \\
\text { untuk } \\
\text { pengembangan } \\
\text { UMKM } \\
\text { masyarakat. } \\
\text { Sehinga pihak } \\
\text { investor asing } \\
\text { yang mulai } \\
\text { membuka } \\
\text { industry Budi } \\
\text { daya teripang saat } \\
\text { ini. }\end{array}$ \\
\hline
\end{tabular}

\begin{tabular}{|c|c|c|}
\hline & $\begin{array}{lr}\text { sehingga } & \\
\text { menambah } & \\
\text { jumlah } & \\
\text { tenagakerja } & \\
\text { rumahan, dan } \\
\text { pekerja pada } \\
\text { perusahaan } & \text { yang } \\
\text { bergerak pada } \\
\text { budidaya } & \\
\text { tersebut. } & \end{array}$ & \\
\hline $\begin{array}{l}\text { Pemerinta } \\
\text { h Desa }\end{array}$ & $\begin{array}{l}\text { Untuk pelayanan } \\
\text { administrasi desa } \\
\text { memiliki kantor } \\
\text { Desa, Unit } \\
\text { Pelayanan } \\
\text { Kesehatan. } \\
\text { Badan } \\
\text { Permusyawarata } \\
\text { n Desa (BPD) }\end{array}$ & $\begin{array}{l}\text { Jarak antar Desa } \\
\text { dengan Ibu Kota } \\
\text { Kecamatan dan } \\
\text { Kabupaten } \\
\text { terpisah oleh } \\
\text { pulau dan laut, } \\
\text { sehingga untuk } \\
\text { berkoordinasi } \\
\text { memakan waktu } \\
\text { lebih dari satu } \\
\text { hari }\end{array}$ \\
\hline
\end{tabular}

Strategi yang dapat dilakukan berdasarkan Matriks Analisis SWOT diatas adalah :

\section{Offensive/competitive strategies (SO)}

Stretegi ini merupakan strategi yang bersifat kuat dengan memanfaatkan peluang yang ada dengan kekuatan yang dimiliki. Strategi yang dapat dilakukan adalah :

a. Melakukan identidfikasi sektor ataupun objek wisata yang memiliki potensi tinggi untuk berkembang dan diminati wisatawan

b. Mengoptimalkan dan melakukan tindakan efisiensi dalam penyediaan fasilias pendukung diantaranya transportasi khusus dengan harga tiket yang proporsional untuk angkutan wisatawan ke 
Desa Pulau Benan lokasi objek wisata.

c. Membuka investasi ataupun mengupayakan pembangunan fasislitas penunjang lainnya seperti sarana pelabuhan khusus untuk kunjungan objek wisata, karena pelabuhan saat ini ada kendala kapal sandar jika cuaca dan angin tidak mendukung.

d. Mengidentifikasikan produk yang memiliki daya tarik dan bernilai ekonomis tinggi dan membuat produk tersebut menjadi produk unggulan yang menjadi ciri khas desa yang menarik wisatawan

e. Memfokuskan kegiatan wisata dengan menggunakan sumber daya yang dimiliki masyarakat sehingga masyarakat terlibat langsung dan mendapatkan keuntungan dari hal tersebut

\section{Diversification strategies (ST)}

Melalui strategi ini, maka diharapkan desa Pulau Benan dapat mengurangi ancaman yang ada. Strategi yang dapat dilakukan adalah

a. Membangun ciri khas yang mudah diingat oleh masyarakat luas yang membedakan Desa Pulau Benan dengan desa lain yang hampir mempunyai potensi yang sama.

b. Berkoordinasi dengan pemerintah daerah yang memiliki hierarki yang lebih tinggi khususnya dengan Dinas Pariwisata untuk membantu dan memberikan masukan terhadap upaya pembangunan dan perintisan desa Wisata Pulau Benan. c. Membangun system jaringan tekhnologi informasi/komunikasi yang efektif untuk mengenalkan Desa Wisata Pulau Benan kepada khalayak dalam dan luar negeri bekerjasama dengan tenaga ahli di perguruan tinggi tedekat.

d. Membangun pemikiran masyarakat mempromosikan desa Pulau Benan merupakan desa yang tanggap terhadap perubahan dan trend teknologi serta mengetahui trend wisata yang ada.

e. Memahami lebih dalam mengenai konsep desa wisata sehingga dapat melakukan perencanaan yang tepat berdasarkan pemahaman yang lebih dalam dan mengikutsertakan seluruh masyarakat Desa Pulau Benan untuk turut berpartisipasi dalam setia proses pembangunan

\section{Overview strategies (WO)}

Melalui strategi ini, maka diupayakan adanya kemampuan memperkecil kelemahan dengan memanfaatkan peluang eksternal yang ada. Strategi yang dapat dilakukan adalah

a. Bekerja sama dengan pemerintah atau aparat desa untuk dapat menciptakan memberikan kemudahan akses fasiltas pelatihan/pembinaan bagi generasi muda dan ibu-ibu rumah tangga mengikuti pelatihan berwirausaha.

b. Memperbaiki kemampuan dasar pendidikan sebagaian besar masyarakat yang belum menempuh pendidikan minimal 12 tahun, bekerja sama dengan pemerintah daerah sehingga dapat meningkatkan kualitas sumber daya manusia.

c. Mengenalkan masyarakat dengan perkembangan teknologi yang dapat membantu memudahkan aktifitas sehari-hari serta dibutuhkan pelatihan secara khusus dalam upaya melakukan 
promosi terhadap keunikan dunia pariwisata Desa Pulau Benan.

d. Bekerja sama dengan Kecamatan untuk memperbaiki infrastruktur berupa jalan dan fasilitas umum seperti air bersih. Lokalisasi hewan ternak seperti kambing agar tidak menyisakan kotoran pada ruas jalan. .

\section{Defensive strategies (WT)}

Dengan strategi ini maka ditujukan untuk mengurangi kelemahan serta relatif menghindari ancaman yang ada.

a. Memberikan pelatihan bagaimana berinteraksi, meningkatkan kerampilan bidang seni dan budaya, agar dengan pengunjung wisata dan meningkatkan kualitas sumber daya manusia secara keseluruhan Seminar Nasional Manajemen pengelolaan wisata bahari.

b. Mengajak seluruh masyarakat untuk dapat berpartisispasi dalam upaya perintisan desa wisata Pulau Bdenan baik dalam pembangunan maupun upaya lainnya.

c. Membuat peraturan yang disepakati bersama dalam upaya mewujudkan tujuan bersama untuk menciptakan desa Pulau Benan menjadi desa wisata yang diminati wisatawan

Berdasarkan analisa yang telah diungkapkan, maka hal ini akan sangat membantu apabila terdapat aplikasi yang memiliki kaitan dengan upaya peningkatan wisatawan menggunakan pengelolaan yang lebih profesional. Kami menyarankan inovasi aplikasi ToGo(Tour Guide Online) untuk membantu pemerintah agar meningkatkan pariwisata yang ada di Kabupaten Lingga khususnya Desa Pulau Benan. Tidak hanya untuk meningkatkan pariwisata di Kabupaten Lingga aplikasi ini juga dapat meningkatkan perekonomian masyarakat Kabupaten Lingga khususnya Desa
Pulau Benan, dan Kabupaten Lainnya di Kepulauan Riau.

Untuk mendukung peningkatan pariwisata di Kabupaten Lingga khususnya Desa Pulau Benan, pemerintah juga harus turut ambil bagian. Pemerintah dapat mengadakan pelatihan seni dan budaya serta melengkapi fasilias yang diperlukan mendukung kegiatan wisatawan.

\section{KESIMPULAN}

Salah satu upaya untuk meningkatkan pendapatan negara dimulai dari peningkatan kesejahteraan masyarakat tiap daerah. Upaya yang dapat dilakukan adalah mengolah potensi wisata daerah yang ada sehingga bisa berkontribusi memberikan pemasukan daerah serta meningkatkan taraf hidup rakyat. Dengan adanya daya tarik kebudayaan dan alam yang memang menjadi potensi wisata maka hal ini dapat menjadi kekuatan bagi daerah untuk memulai mengolah potensi wisata yang dimiliki. Namun hal ini tentunya memiliki serangkaian hambatan yang perlu diatasi terkait dengan kesiapan kondisi desa. Oleh karena itu, dengan menggunakan analisis SWOT maka diharapkkan dapat disusun strategi terkait kekuatan maupun kelemahan sehingga dapat menjadi solusi untuk menghadapi ancaman dengan mengambil peluang yang ada. Dengan adanya strategi pengembangan yang telah ditetapkan, diharapkan hal ini menjadi salah satu upaya untuk mempercepat usaha perintisan Desa wisata. Rekomendasi terkait dengan strategi pengembangan potensi Desa Pulau Benan ditujukan baik kepada pemerintahan daerah maupun masyarakat desa untuk dapat bersinergi menyatukan tujuan untuk dapat merintis desa wisata sesuai dengan potensi yang dimiliki.

\section{KETERBATASAN}

Keterbatasan karya tulis ini adalah hanya menggunakan sumber-sumber dari literature dalam penulisan karya. Selain itu penulis hanya 
mengungkapkan ide gagasan berdasarkan analisis yang digunakan dan terkait dengan inovasi system pemasaran 4.0

\section{UCAPAN TERIMAKASIH}

Disampaikan terimakasih kepada semua pihak yang mendukung program ini. Semoga bermanfaat bagi kepentingan kesejahteraan masyarakat setempat serta mampu memberikan pelayanan wisatawan yang lebih baik lagi.

\section{DAFTAR PUSTAKA}

A Demartoto - 2009, Pembangunan pariwisata berbasis masyarakat - Sebelas Maret, University Press.

Dharasta, Dyahjatmayanti, Nieama. 2017. Analisis SWOT Desa Wisata di Kabupaten Sleman. Jurnal Manajemen. Vol 7, No 2 (2017): $42-50$

Dinas Pariwisata Pemuda dan Olahraga (Disparpora, Kab.Lingg; 2016)

Fitra, Tumiati. Analisis SWOT untuk Strategi Pengembangan Obyek Wisata Pemandian Mual Mata Kecamatan Pematang Bandar Kabupaten Simalungun. Jurnal Pendidika Geografi Universitas Negeri Medan e-ISSN: 2549-7057| p-ISSN: 2085-8167.

Freddy, Rangkuti. 2014. Analisis SWOT Teknik Membedah Kasus Bisnis. Jakarta: PT. ramedia.

Journal of Development and Social Change, Vol. 1, No. 1, April 2018: P. 9-17 p-ISSN 2614 5766, https: //jurnal.uns.ac.id/jodasc Karina Wulan Sayogi, Argyo Demartoto

Karyono, Har,1997 Kepariwisataan. Jakarta: Gramedia Widia Sarana Indonesia

Pitana, I.G., 2002, Pariwisata, Wahana Pelestarian Kebudayaan dan Dinamika Masyarakat Bali, Denpasar: Universitas Udayana.
Priasukmana, Soetarso dan R. Mohamad Mulyadin. 2001. "Pembangunan Desa Wisata: Pelaksanaan Undang-Undang Otonomi Daerah". Jurnal Info Sosial Ekonomi. Vol.2 No.1 (2001) pp. 37 - 44.

Sastrayudha, Gumelar. 2010. "Strategi Pengembangan dan Pengelolaan Resort dan Leisure".Online.(http://www.jurnal.triatmulya.a c.id/index.php /JMPII/view/12/13, tanggal 27 Oktober 2016).

Sleman. Jurnal Manajemen. Vol 7, No 2 (2017): 42 - 50 Fitra, Tumiati 